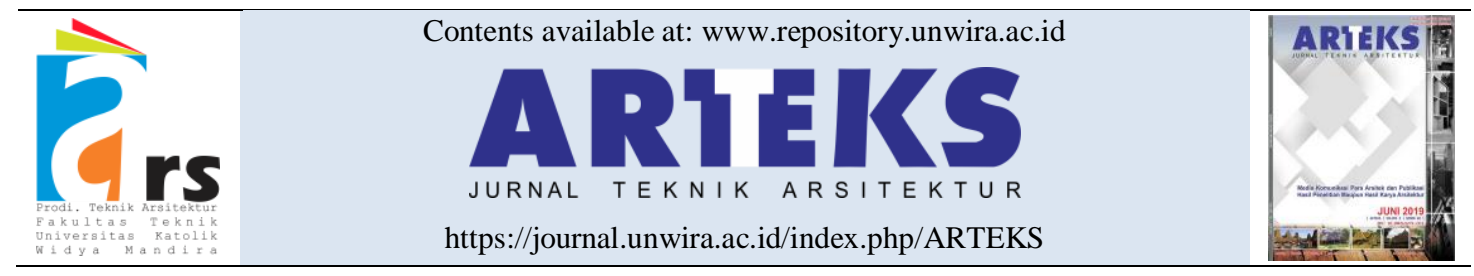

Research paper

doi: 10.30822/arteks.v5i2.394

\title{
Karakteristik desain ruang terbuka hijau pada sempadan sungai perkotaan
}

\section{Kusriantari Fenny Aprillia*, Titieandy Lie, Chairul Saputra}

Program Studi Arsitektur, Institut Teknologi Indonesia

Jl. Raya Puspiptek Serpong, Tangerang Selatan, Indonesia

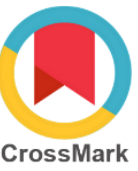

\begin{tabular}{l}
\hline ARTICLE INFO \\
\hline Article history: \\
Received February 14, 2020 \\
Received in revised form March 03, \\
2020 \\
Accepted April 18, 2020 \\
Available online August 01, 2020
\end{tabular}

Keywords:

Ecological function of green open space

Green open space of river border

Social function of green open space

Urban green open space

ABSTRACT

Characteristics of green open space design on urban river borders

The design of green open space on the urban river border should be able to fulfill ecological and social functions like other types of green open space. Green open space of Teras Cikapundung, green open space of Jaletreng River Park, and green open space of Taman Kaulinan have their design characteristics in realizing both functions. This study aims to uncover the characteristics of green open space design on the urban river border. The method used is descriptive qualitative. The analysis shows that the three objects of research have similarities and differences that complement each other to fulfill ecological and social functions. Ecological functions can be fulfilled well in the green open space of Teras Cikapundung and green open space of Jaletreng River Park, while the social services can be performed well in the all three green open spaces. The conclusion obtained, i.e. (a) in terms of ecological functions and social functions must be fulfilled in a balanced manner, (b) because it is located in the river border area, it is expected that the river can

*Corresponding author: Kusriantari Fenny Aprillia

Program Studi Arsitektur, Insitut Teknologi Indonesia

Email: fenny.aprillia@iti.ac.id be used as a potential in fulfilling ecological and social functions, (c) the river border area is maintained its natural area so that animal habitat can be managed, but can be integrated with artificial areas such as reinforcement to prevent erosion and river sedimentation, (d) the river body can be used as a visitor attraction Namely by designing a sitting space facing the river, developing a circulation area along the river border, and holding river games.

\section{Pendahuluan}

RTH (Ruang Terbuka Hijau) merupakan area memanjang/jalur dan/atau mengelompok, yang penggunaannya lebih bersifat terbuka, tempat tumbuh tanaman, baik yang tumbuh secara alamiah maupun yang sengaja ditanam (Presiden Republik Indonesia 2007). Menurut Permen PU (2008), proporsi RTH pada wilayah perkotaan adalah minimal $30 \%$ dari luas total wilayah perkotaan (Direktoran Jenderal Penataan Ruang Departemen Pekerjaan Umum 2008).

Menanggapi peraturan perundang-undangan tersebut, beberapa kota di Indonesia mulai membangun dan merevitalisasi RTH kotanya. Salah satu kota yang mengalami peningkatan luas RTH secara signifikan adalah Kota Surabaya, peningkatan yang terjadi adalah sebesar $116 \%$ dalam rentang tahun 2000-2013, tahun 2013 Kota Surabaya telah berhasil memiliki luas RTH sebesar 40\% (Budiman, Sulistyantara, and Zain 2014). Kota Bandung juga memiliki tren yang meningkat. Menurut Dinas Perumahan dan Kawasan Permukiman, Pertanahan dan Pertamanan Kota Bandung dalam rentang waktu tahun 2008-2015 memiliki peningkatan sebesar 3,6\%, namun luas RTH Kota Bandung tahun 2015 
masih dibawah $30 \%$ yaitu hanya sebesar $12,15 \%$ (Widyahantari and Rudiarto 2018).

Beberapa kota yang berusaha meningkatkan luas RTH-nya telah menyadari bahwa RTH memiliki fungsi penting yang dapat meningkatkan kualitas hidup dari warganya. Menurut Permen PU no. 5 tahun 2008, RTH memiliki fungsi yang terbagi menjadi fungsi ekologis, fungsi sosial budaya, fungsi ekonomi, dan fungsi estetika (Direktoran Jenderal Penataan Ruang Departemen Pekerjaan Umum 2008). Tidak hanya sebagai paru-paru kota, RTH juga berfungsi sebagai wadah bersosialisasi, rileksasi, bahkan sebagai wajah dari perkotaan. Fungsi ekologis merupakan fungsi utama dari RTH (Liem and Lake 2018).

Salah satu usaha untuk meningkatkan luas RTH kota yang banyak dilakukan di kota-kota besar di Indonesia adalah dengan memanfaatkan area sempadan sungai (Fatah, Nugraha, and Haniah 2015). Usaha penghijauan pada area sempadan sungai banyak dilakukan untuk mencegah adanya erosi, penyediaan habitat satwa, konservasi air, dan lain sebagainya. Namun masih sedikit wilayah perkotaan yang memanfaatkan sempadan sungai selain berfungsi sebagai ekologis dapat juga berfungsi secara sosial. Atau bahkan area sempadan sungai telah hilang fungsi ekologisnya akibat perubahan bentuk dari sungai alami menjadi kanal, hal ini banyak terjadi pada wilayah perkotaan dengan daerah aliran sungai hilir (dekat dengan muara). Dengan adanya fenomena tersebut daerah sempadan sungai wilayah perkotaan diharapkan mampu mewadahi fungsi ekologis dan fungsi sosial secara sekaligus seperti yang tertuang pada peraturan perundang-undangan.

Mempelajari karakteristik desain dari RTH sempadan sungai bermanfaat untuk mengetahui fungsi ekologis dan fungsi sosial yang diwadahinya (Hartoyo and Santoni 2018). Diharapkan dengan adanya penelitian ini, kekurangan dan kelebihan RTH sempadan sungai tiap kota dapat menjadi pelajaran bagi kota lain yang akan membangun RTH pada sempadan sungai. RTH sempadan sungai yang terpilih untuk dijadikan objek penelitian adalah Teras Cikapundung (Kota Bandung), Jaletreng River
Park (Kota Tangerang Selatan), dan Taman Kaulinan (Kota Bogor).

\section{Metode penelitian}

Metode yang digunakan dalam penelitian ini adalah metode deskriptif kualitatif. Penelitian ini akan mengamati tiga buah RTH dari segi fungsi sosial maupun ekologis.

Pengumpulan data dilakukan pada tiga lokasi RTH sempadan sungai terpilih di wilayah perkotaan. Pengumpulan data dilakukan dengan cara observasi lapangan yaitu dengan mengamati fungsi ekologis maupun fungsi sosial pada RTH. Selain itu dilakukan wawancara terhadap pengunjung terkait fungsi sosial dari RTH. Wawancara dilakukan guna melengkapi data dari proses pengamatan.

Pengamatan pada fungsi ekologis yaitu mengamati vegetasi sesuai dengan fungsinya sebagai paru-paru kota, penjaga iklim mikro, peneduh, penahan angin, dan kaitannya dengan ekologi sungai. Vegetasi diamati berdasarkan jenis, peletakan, serta desain penanamannya.

Pengamatan pada fungsi sosial yaitu mencakup fungsi sosial apa saja yang diwadahi dalam RTH. Hal-hal yang diamati adalah fasilitas yang disediakan pada RTH, aktifitas apa saja yang dapat dilakukan, serta hubungan antara RTH dengan aliran sungai.

Analisis dilakukan setelah data terkumpul dari ketiga lokasi pengamatan. Data dianalisis dengan metode komparatif yaitu membandingkan antara lokasi satu dengan lokasi lain dalam koridor fungsi ekologis dan fungsi sosial. Diperlukan adanya kriteria-kriteria hasil pengamatan yang disajikan dalam bentuk tabel, sehingga data pengamatan secara deskriptif dapat di input sesuai dengan kriteria-kriteria tersebut. Selanjutnya dilakukan komparasi antar ketiga lokasi pengamatan hingga menghasilkan kesimpulan berupa karakteristik desain RTH pada area sempadan sungai di wilayah perkotaan. Tabel kriteria hasil pengamatan tercantum dalam tabel 1. 
Tabel 1. Kriteria hasil pengamatan

\begin{tabular}{|c|c|}
\hline Kriteria & Indikator \\
\hline \multicolumn{2}{|r|}{ Fungsi ekologis } \\
\hline $\begin{array}{l}\text { Vegetasi } \\
\text { penghasil } \\
\text { oksigen dan } \\
\text { penyerap } \\
\text { polusi udara }\end{array}$ & $\begin{array}{l}\text { Karakteristik Vegetasi: } \\
\text { - Bermassa daun padat (Direktoran Jenderal Penataan Ruang Departemen Pekerjaan Umum 2008). } \\
\text { - Berumur muda dan tajuk rindang (Ramdhani and Fatimah 2013) } \\
\text { - Serapan } \mathrm{CO}_{2} \text { untuk pohon hutan: 58,26 ton/ha, serapan } \mathrm{CO}_{2} \text { untuk semak: 3,30 ton/ha (Lukmanniah and } \\
\text { Fatimah 2016) } \\
\text { Karakteristik Penanaman: } \\
\text { - Jarak tanam rapat, terdiri dari pohon, perdu/semak (Direktoran Jenderal Penataan Ruang Departemen } \\
\text { Pekerjaan Umum 2008). }\end{array}$ \\
\hline $\begin{array}{l}\text { si } \\
\text { a iklim }\end{array}$ & $\begin{array}{l}\text { Karakteristik Vegetasi: } \\
\text { - Bermassa daun padat (Direktoran Jenderal Penataan Ruang Departemen Pekerjaan Umum 2008). } \\
\text { - Kanopi pohon lebar (Bowler et al. 2010). } \\
\text { - Pohon memiliki percabangan } 2 \mathrm{~m} \text { di atas tanah, perawakan tinggi, tajuk saling bersinggungan (Erdianto, } \\
\text { Rofiqo Irwan, and Kastono 2019). } \\
\text { Karakteristik Penanaman: } \\
\text { - Individual atau berkelompok, banyak rumput dari pada perkerasan (Bowler et al. 2010). }\end{array}$ \\
\hline si & $\begin{array}{l}\text { Karakteristik Vegetasi: } \\
\text { - Bermassa daun padat (Direktoran Jenderal Penataan Ruang Departemen Pekerjaan Umum 2008). } \\
\text { - Berdaun jarum, percabangan dekat permukaan tanah, bertekstur daun kasar (Adjam and Renoat 2017). } \\
\text { Karakteristik Penanaman: } \\
\text { - Terdiri dari tanaman tinggi, perdu/semak, ditanam berbaris atau membentuk massa, jarak tanam rapat < } \\
3 \text { m (Direktoran Jenderal Penataan Ruang Departemen Pekerjaan Umum 2008) } \\
\text { - Jarak tanam 5-10 m untuk tanaman pohon tinggi, semak, rumput, serta 2-5 m untuk tanaman pohon tinggi } \\
\text { dan pohon rendah (Adjam and Renoat 2017). }\end{array}$ \\
\hline si & $\begin{array}{l}\text { - Komposisi vegetasi beragam dengan strata rapat, kerapatan tajuk tinggi, bentuk daun besar (Madjowa } \\
\text { 2017). } \\
\text { - Perkerasan < } 45 \% \text { luas (Madjowa 2017). }\end{array}$ \\
\hline $\begin{array}{l}\text { gahan } \\
\text { sungai }\end{array}$ & $\begin{array}{l}\text { - Vegetasi rumput-rumputan meminimalisir terjadi aliran permukaan dan erosi, vegetasi hutan berperan } \\
\text { dalam menghalangi pukulan air hujan terhadap permukaan tanah (Naharuddin 2018). } \\
\text { - Membangun penguat pada area yang rentan terkena erosi, terutama pada tikungan sungai (dinding turap, } \\
\text { beton, dan bronjong). } \\
\text { - Pohon tahan genangan yaitu: Albizia, jayanti, karet, kopi, pinus, kenari, jambu monyet, dan kapuk randu } \\
\text { (Angelia 2017). }\end{array}$ \\
\hline $\begin{array}{l}\text { Pencegahan } \\
\text { sedimentasi } \\
\text { sungai }\end{array}$ & $\begin{array}{l}\text { ngurangi terjadinya erosi } \\
\text { nurunkan kecepatan arus sungai dengan cara pelebaran badan sungai }\end{array}$ \\
\hline $\begin{array}{l}\text { Vegetasi } \\
\text { penyerap } \\
\text { polusi air }\end{array}$ & $\begin{array}{l}\text { - Akar pohon yang ditanam di sepanjang tepi sungai dan tahan terhadap tekanan air, dapat menyaring } \\
\text { nutrient berbahaya dalam air tanah sebelum nutrient tersebut mengalir ke badan sungai. } \\
\text { - Pohon gempol adalah salah satu vegetasi penahan erosi dan penyerap polutan disekitar muara sungai } \\
\text { (Nurika, Wiryani, and Jumari 2019). }\end{array}$ \\
\hline $\begin{array}{l}\text { Penyedia } \\
\text { habitat satwa }\end{array}$ & $\begin{array}{l}\text { - Vegetasi menyediakan nutrient dan sebagai habitat hewan darat dan air (Kantartzis et al. 2006). } \\
\text { - Pohon dengan kanopi lebar dan menaungi badan sungai dapat menurunkan suhu air pada palung sungai } \\
\text { dan merupakan habitat yang baik bagi satwa air, biokoridor sungai merupakan sarana yang baik bagi } \\
\text { migrasi satwa. }\end{array}$ \\
\hline Kriteria & \\
\hline \multicolumn{2}{|r|}{ Fungsi sosial } \\
\hline $\begin{array}{l}\text { - Media kom } \\
\text { alam (Dire } \\
\text { - Area berm } \\
\text { pelarian da } \\
\text { - Interaksi sc } \\
\text { - Fasilitas u } \\
\text { (Imansari a } \\
\text { - Adanya de }\end{array}$ & $\begin{array}{l}\text { varga kota; tempat rekreasi; wadah dan objek pendidikan, penelitian, dan pelatihan dalam mempelajari } \\
\text { nderal Penataan Ruang Departemen Pekerjaan Umum 2008). } \\
\text { area olahraga dan rekreasi, tempat bertemu untuk grup kecil, tempat bertemu untuk grup besar, tempat } \\
\text { ingan dari kehidupan kota (Givoni 1991). } \\
\text { na rekreasi (Dwiyanto 2009). } \\
\text { im dengan fungsi rekreasi, pendidikan dan olahraga, serta menjalin komunikasi antar warga kota } \\
\text { iyanta 2015). } \\
\text { dayaan setempat (Persada, Putri, and Prasetya 2018). }\end{array}$ \\
\hline
\end{tabular}

Temuan dan pembahasan

Hasil observasi RTH sempadan sungai terpilih Teras Cikapundung (Bandung)
Teras Cikapundung merupakan RTH sempadan sungai yang terletak pada segmen Sungai Cikapundung. RTH ini meliputi kedua koridor sungai. 
Secara fungsi ekologis RTH Teras Cikapundung memiliki karakteristik desain vegetasi yang sangat baik. Seluruh kriteria dalam fungsi ekologis berhasil dipenuhi. Keunggulan dari fungsi ekologis RTH ini yaitu tersedianya area alami/natural yang mempertahankan vegetasi asli sempadan sungai yaitu beberapa diantaranya adalah pohon hutan (Lihat gambar 1). Desain vegetasi hanya terdapat pada area air mancur, amphitheater, dan kolam ikan (Lihat gambar 2). Selebihnya dibiarkan alami seperti aslinya karena terdapat pohon-pohon tua yang tidak mungkin dihilangkan. Sistem yang dipakai pada sungai untuk pencegahan erosi dan sedimentasi yaitu dibangun struktur penguat berupa beton, dinding turap, serta karung yang berisi tanah. Namun, penguat tersebut tidak dibangun di seluruh sisi sempadan sungai, selebihnya dibiarkan alami.

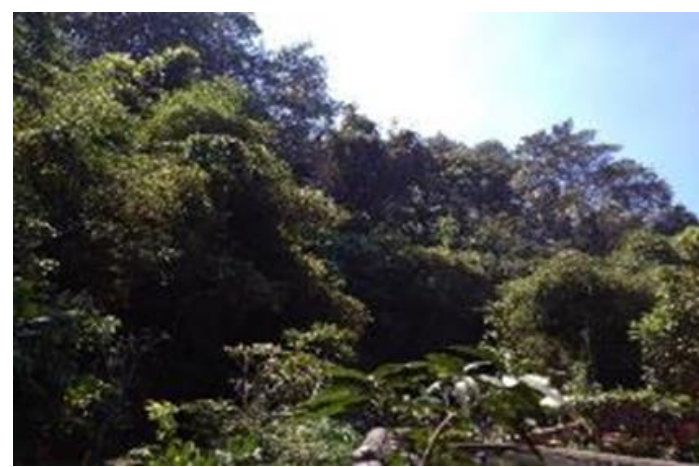

Gambar 1. Area alami/natural

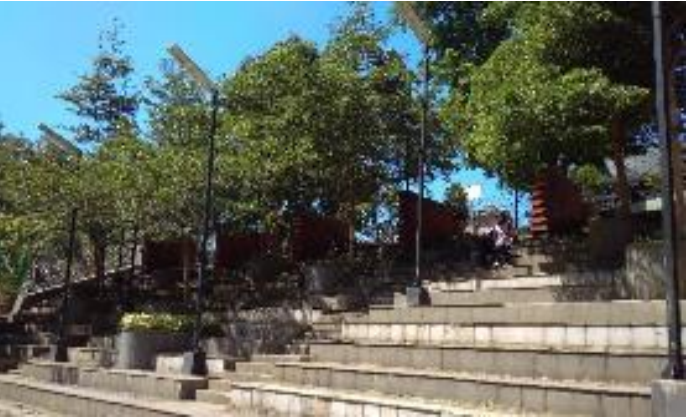

Gambar 2. Desain vegetasi pada amphitheater

Dilihat dari fungsi sosial, RTH Teras Cikapundung banyak digunakan sebagai tempat berkumpul komunitas, interaksi warga sekitar, tempat rekreasi, serta tempat bermain bagi anakanak. Namun untuk fasilitas olahraga tidak tersedia pada pada RTH ini. Terdapat interaksi pengunjung dengan Sungai Cikapundung yaitu dengan desain amphitheater dan area duduk yang menghadap ke arah sungai (Lihat gambar 3). Selain itu terdapat permainan anak berupa perahu karet (Lihat gambar 4) yang memanfaatkan arus sungai. Terlihat pula beberapa warga sekitar yang memancing.

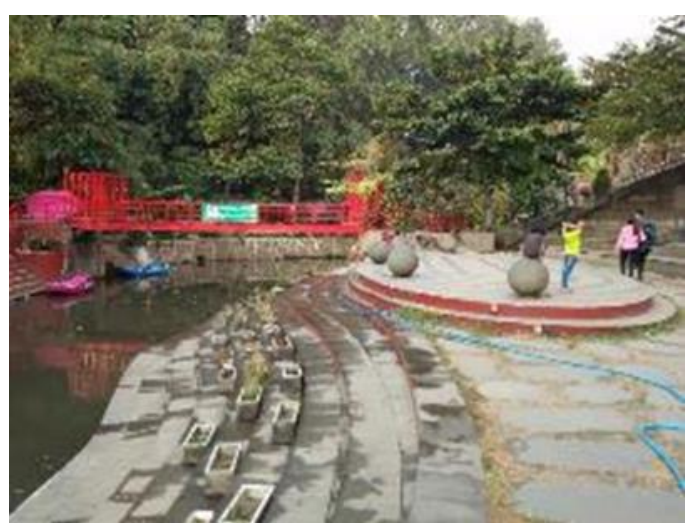

Gambar 3. Amphitheater menghadap ke sungai



Gambar 4. Permainan perahu karet

Jaletreng River Park (Tangerang Selatan)

Jaletreng River Park merupakan RTH sempadan sungai yang terletak di Kota Tangerang Selatan pada segmen anak Sungai Cisadane. RTH Jaletreng River Park meliputi kedua koridor sungai. RTH sempadan sungai ini menyatu dengan RTH Taman Kota 2 Bumi Serpong Damai.

Secara fungsi ekologis RTH ini telah memenuhi kriteria-kriteria ekologis. Terdapat biokoridor pada salah satu koridor yang memiliki banyak manfaat dalam fungsi ekologis (Lihat gambar 5). Letak RTH yang menyatu dengan RTH taman kota juga merupakan salah satu keunggulan dari sisi ekologis. Biokoridor memiliki fungsi dalam penyerapan polusi, penghasil oksigen, penjaga iklim mikro, penahan angin, penyerap air, penyerap polusi air, dan penyedia habitat satwa. Sistem yang digunakan 
dalam pencegahan erosi dan sedimentasi yaitu dengan cara membangun penguat dari beton dan dinding turap. Selain itu pada sepanjang bibir sungai terdapat vegetasi penutup tanah yang tumbuh secara liar, membantu memperkuat tanah dari erosi. Pelebaran badan sungai juga dilakukan pada RTH ini dengan tujuan untuk menambah volume tampungan air dan menurunkan kecepatan arus sungai sehingga air tidak dengan mudah mengerosi tanah.

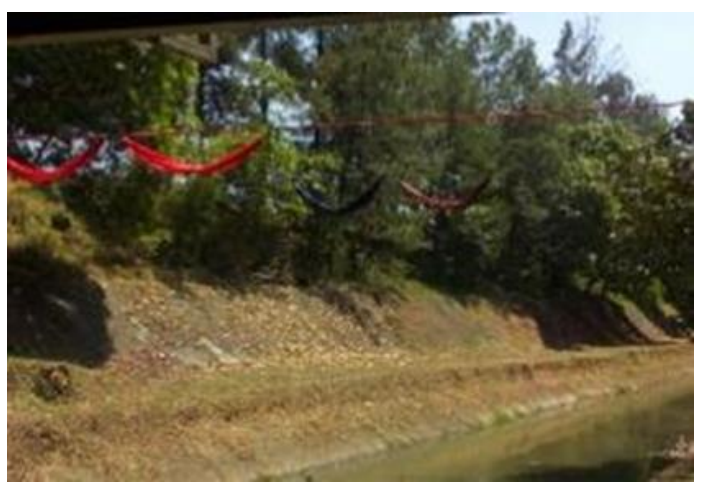

Gambar 3. Biokoridor

Secara fungsi sosial RTH ini banyak dimanfaatkan sebagai area interaksi warga sekitar, area rekreasi, area bermain, area olahraga, dan bertemunya grup kecil serta grup besar. Pada RTH ini belum tersedia objek pendidikan, penelitian, dan pelatihan. Terdapat interaksi antara pengunjung dengan sungai yaitu terlihat dari desain amphiteater dan area duduk yang menghadap sungai. Selain itu, terdapat jogging track di sepanjang sempadan sungai (Lihat gambar 6). Interaksi lain yaitu dengan adanya permainan perahu bebek yang dijadikan pengunjung sebagai sarana rekreasi. Meskipun sungai ini memiliki lebih banyak area buatan daripada area alami, namun perancang RTH tidak melupakan sungai sebagai bagian dari aktifitas pengunjung.

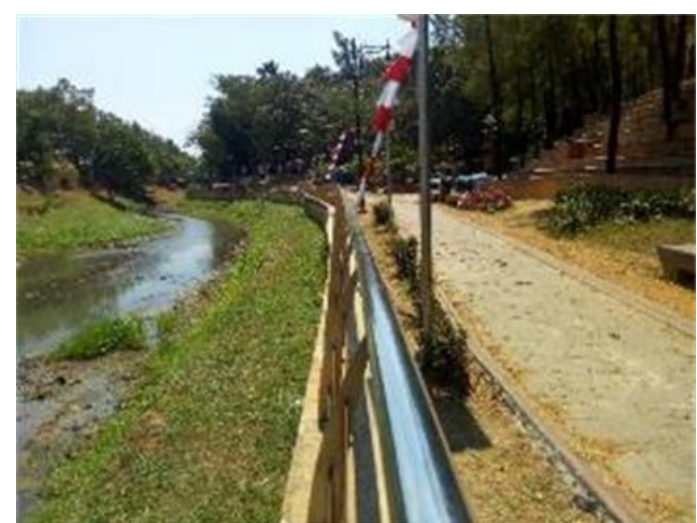

Gambar 4. Jogging track di sepanjang sempadan sungai

Taman Kaulinan (Bogor)

Taman Kaulinan merupakan RTH sempadan sungai yang terletak pada segmen Sungai Ciliwung. RTH ini terletak satu area dengan Lapangan Sempur dan hanya menempati satu sisi koridor.

Dilihat dari segi ekologis RTH Taman Kaulinan memiliki banyak kekurangan. Keadaan eksisting yang hanya memiliki sedikit pohon dari segi jumlah dan keberagamannya, membuat RTH ini memiliki kekurangan dalam fungsi ekologisnya. RTH ini dirasa kurang dalam penjaga iklim mikro, karena area perkerasan lebih dominan dibandingkan rumput. Fungsi penahan angin juga tidak dimiliki dikarenakan karakteristik penanaman pohon dilakukan secara individu dan menyebar, sehingga kurang efektif dalam menahan angin. Sistem pencegahan erosi sungai dilakukan dengan cara membangun penguat berupa dinding turap (Lihat gambar 7) di sepanjang sisi sempadan sungai, sehingga tidak memiliki area alami untuk habitat vegetasi sepanjang sisi sungai, selain itu tidak adanya sistem penyerapan polusi air sungai oleh vegetasi sempadan sungai. Keberagaman vegetasi terdapat pada perdu, semak, dan penutup tanah untuk kebutuhan estetika. 


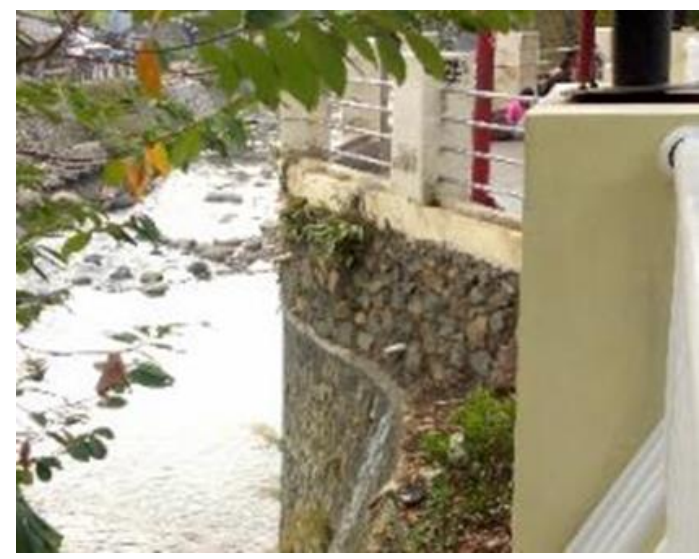

Gambar 5. Dinding turap di sepanjang sempadan sungai

Fungsi sosial pada RTH Taman Kaulinan lebih dominan dibandingkan fungsi ekologis. RTH ini memiliki banyak fasilitas olahraga (Lihat gambar 8), karena letaknya berdekatan dengan lapangan Sempur. Tersedia lapangan basket, area panjat tebing, area skate board, dan fitness. Fungsi sosial lain yang diwadahi pada RTH ini adalah area bermain berupa playground, wadah interaksi warga, dan sarana rekreasi. Pengunjung yang datang pada RTH ini tidak dapat berinteraksi dengan sungai dikarenakan desain dari RTH ini tidak menghadap sungai. Terdapat pagar di sepanjang dinding turap sehingga, pengunjung tidak dapat menikmati sungai.

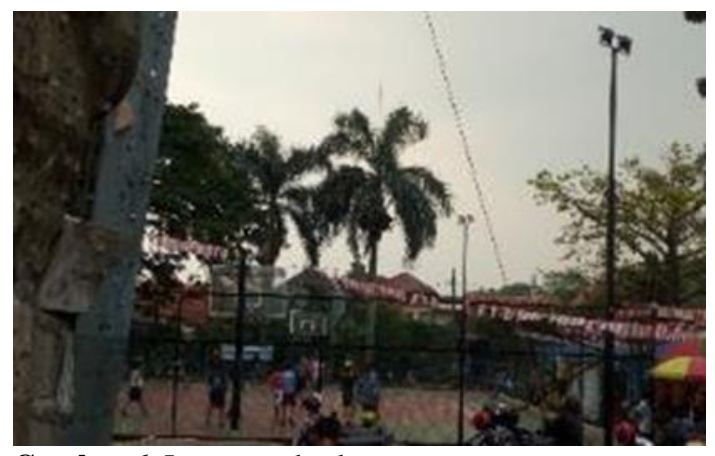

Gambar 6. Lapangan basket

\section{Hasil rekapitulasi analisis RTH sempadan sungai terpilih}

Analisis fungsi ekologis dan sosial pada ketiga RTH sempadan sungai tertera dalam tabel 2 . Karakteristik desain RTH sempadan sungai dilihat dari fungsi ekologis dan sosial pada ketiga lokasi tersebut, memiliki persamaan dan perbedaan yang saling melengkapi.
Pemenuhan fungsi ekologis RTH yang baik terdapat pada RTH Teras Cikapundung dan Jaletreng River Park. Pemilihan dan cara penanaman vegetasi pada kedua RTH tersebut dapat memenuhi seluruh kriteria fungsi ekologis. Keberagaman jenis pohon pada area alami RTH Teras Cikapundung dan biokoridor RTH Jaletreng River Park merupakan potensi dalam pemenuhan fungsi ekologis. Sehingga kedua RTH memainkan perannya dengan baik dalam pemenuhan fungsi ekologis. Selain itu, hubungannya dengan aliran sungai, kedua RTH tetap menjaga area alami dan memadukan dengan area buatan berupa dinding penguat untuk mencegah erosi dan sedimentasi. Dengan adanya konservasi area alami sungai, keberadaan satwa asli dapat lestari dikarenakan habitatnya terjaga. Hal ini yang perlu dicermati dalam RTH sempadan sungai khususnya di wilayah perkotaan. Pada RTH Taman Kaulinan fungsi ekologisnya kurang dipenuhi dengan baik, dikarenakan keberagaman dan jumlah pohon sangat minim. Selain itu tidak adanya konservasi area alami sungai pada RTH ini menyebabkan berubahnya keadaan eksisting sungai.

Dilihat dari segi sosial, ketiga RTH sudah mampu memenuhi fungsi sosial dengan baik. Seluruh warga dari berbagai kalangan dapat memanfaatkan ketiga RTH ini untuk berinteraksi dan berekreasi. Namun, pada RTH Teras Cikapundung tidak tersedia fasilitas olahraga. Sedangkan kriteria objek pendidikan, penelitian, dan pelatihan hanya ditemui pada RTH Teras Cikapundung. Dari ketiga RTH tersebut RTH Taman Kaulinan adalah yang paling kuat dalam pemenuhan fungsi sosial, dikarenakan RTH ini memiliki fasilitas olahraga yang cukup lengkap dibandingan RTH lain. Namun, Taman Kaulinan memiliki kekurangan pada desain RTH yang tidak memanfaatkan sungai sebagai bagian dari fungsi sosial. Dibandingkan dengan Teras Cikapundung dan Jaletreng River Park, pengunjung Taman Kaulinan tidak dapat mengakses sungai bahkan beraktifitas di badan sungai. Pada Teras Cikapundung dan Jaletreng River Park, desain dari area duduk menghadap ke sungai, sehingga keberadaan sungai menjadi potensi bukan hanya dari segi ekologis tetapi juga dalam segi sosial. Rekreasi perahu karet pada Teras Cikapundung dan perahu bebek pada Jaletreng River Park juga salah satu contoh pemanfaatan sungai dalam fungsi sosial. 
Tabel 2. Hasil analisis fungsi ekologis dan sosial pada ketiga RTH (Ruang Terbuka Hijau) sempadan sungai

\begin{tabular}{|c|c|c|c|}
\hline Kriteria & Teras Cikapundung & Jaletreng River Park & Taman Kaulinan \\
\hline \multicolumn{4}{|c|}{ Fungsi ekologis } \\
\hline $\begin{array}{l}\text { Vegetasi } \\
\text { penghasil } \\
\text { oksigen dan } \\
\text { penyerap polusi } \\
\text { udara }\end{array}$ & $\begin{array}{l}\text { - Sisi koridor yang berbatasan } \\
\text { dengan jalan raya terdapat } \\
\text { pohon mahoni dan trembesi } \\
\text { yang mampu menyerap } \\
\text { polusi udara karena } \\
\text { bermassa daun padat. } \\
\text { - Sisi koridor sebaliknya, } \\
\text { dipenuhi oleh vegetasi } \\
\text { hutan yang mampu } \\
\text { menyerap polusi dan } \\
\text { menghasilkan oksigen. } \\
\text { - Pada area RTH tersebar } \\
\text { berbagai macam perdu dan } \\
\text { semak. } \\
\end{array}$ & $\begin{array}{l}\text { - Lokasi RTH tidak berbatasan } \\
\text { langsung dengan jalan utama, } \\
\text { sehingga polusi udara tidak } \\
\text { terlalu tinggi. } \\
\text { - Tersedia biokoridor dengan } \\
\text { penanaman rapat dan tajuk } \\
\text { lebar dapat menghasilkan } \\
\text { oksigen dengan baik. }\end{array}$ & $\begin{array}{l}\text { Terdapat perpaduan perdu, } \\
\text { semak, dan penutup tanah } \\
\text { sebagai penyerap polusi udara } \\
\text { dan penghasil oksigen. } \\
\text { - Terdapat pohon ketapang } \\
\text { kencana, pohon petai cina, } \\
\text { dan pohon ketapang yang } \\
\text { berdaun padat, dan tajuk } \\
\text { rindang, efektif untuk } \\
\text { penyerap polusi udara dan } \\
\text { penghasil oksigen }\end{array}$ \\
\hline $\begin{array}{l}\text { Vegetasi } \\
\text { penjaga iklim } \\
\text { mikro }\end{array}$ & $\begin{array}{l}\text { - Salah satu sisi koridor } \\
\text { terdapat pohon ketapang } \\
\text { kencana yang ditanam } \\
\text { mengelompok dan tajuk } \\
\text { saling bersinggungan. } \\
\text { - Sisi koridor sebaliknya, } \\
\text { mempertahankan vegetasi } \\
\text { hutan dengan jenis beragam } \\
\text { dan penananaman rapat. }\end{array}$ & $\begin{array}{l}\text { - Tersedia biokoridor yang } \\
\text { terdiri dari pohon dengan tajuk } \\
\text { besar dan ditanam } \\
\text { mengelompok. } \\
\text { - Terdapat sekumpulan pohon } \\
\text { cemara laut yang ditanam rapat } \\
\text { dan cukup memberikan } \\
\text { keteduhan di area duduk. } \\
\text { - Penguat sungai berupa beton } \\
\text { dan dinding turap ditanami } \\
\text { rumput sehingga dapat ikut } \\
\text { serta menurunkan suhu mikro. }\end{array}$ & $\begin{array}{l}\text { Komposisi perkerasan lebih } \\
\text { banyak dari pada rumput. } \\
\text { Tersedia pohon yang dapat } \\
\text { dijadikan penjaga iklim mirko } \\
\text { yaitu pohon kapuk randu, } \\
\text { pohon ketapang, pohon } \\
\text { ketapang kencana, dan pohon } \\
\text { petai cina. }\end{array}$ \\
\hline $\begin{array}{l}\text { Vegetasi } \\
\text { penahan angin }\end{array}$ & $\begin{array}{l}\text { Pada sisi jalan terdapat } \\
\text { pohon mahoni dan trembesi } \\
\text { yang ditanam satu garis } \\
\text { dengan jarak } \pm 4 \text { meter. } \\
\text { - Pada area alami terdapat } \\
\text { banyak pepohonan hutan } \\
\text { dengan penanaman yang } \\
\text { menurun sesuai kontur, } \\
\text { jarak penanaman rapat. }\end{array}$ & $\begin{array}{l}\text { Salah satu sisi koridor pada } \\
\text { area duduk terdapat deretan } \\
\text { pohon cemara laut yang } \\
\text { berdaun jarum dan ditanam } \\
\text { berkelompok. } \\
\text { - Sisi koridor sebaliknya terdapat } \\
\text { biokoridor dengan jenis } \\
\text { vegetasi beragam, penanaman } \\
\text { rapat dan membentuk massa. }\end{array}$ & $\begin{array}{l}\text { Pohon ditanam menyebar } \\
\text { secara individual sehingga } \\
\text { kurang efektif untuk penahan } \\
\text { angin. }\end{array}$ \\
\hline $\begin{array}{l}\text { Vegetasi } \\
\text { penyerap air }\end{array}$ & $\begin{array}{l}\text { - Perbandingan hardscape } \\
\text { dan softscape }=40: 60 \\
\text { Komposisi vegetasi } \\
\text { beragam dan penanaman } \\
\text { rapat pada area alami. }\end{array}$ & $\begin{array}{l}\text { - Perbandingan hardscape dan } \\
\text { softscape }=60: 40 \\
\text { - Salah satu sisi koridor memiliki } \\
\text { kerapatan penanaman pohon } \\
\text { dan tajuk. }\end{array}$ & $\begin{array}{l}\text { Perbandingan hardscape dan } \\
\text { softscape }=75: 25 \\
\text { - Kurang baik dalam } \\
\text { penyerapan air. }\end{array}$ \\
\hline $\begin{array}{l}\text { Pencegahan } \\
\text { erosi sungai }\end{array}$ & $\begin{array}{l}\text { Dibangun penguat berupa } \\
\text { beton, dinding turap, dan } \\
\text { karung berisi tanah pada } \\
\text { area yang rentan terkena } \\
\text { erosi. } \\
\text { Area sempadan ditanami } \\
\text { bambu dan vegetasi penutup } \\
\text { tanah liar (rumput- } \\
\text { rumputan). }\end{array}$ & $\begin{array}{l}\text { Dibangun penguat berupa } \\
\text { beton dan dinding turap } \\
\text { disepanjang koridor sungai. } \\
\text { - Area sempadan ditanami } \\
\text { vegetasi penutup tanah liar } \\
\text { (rumput-rumputan). }\end{array}$ & $\begin{array}{l}\text { Dibangun penguat berupa } \\
\text { dinding turap disepanjang } \\
\text { koridor sungai. }\end{array}$ \\
\hline $\begin{array}{l}\text { Pencegahan } \\
\text { sedimentasi } \\
\text { sungai }\end{array}$ & $\begin{array}{l}\text { Memaksimalkan teknik- } \\
\text { teknik dalam pencegahan } \\
\text { erosi. }\end{array}$ & $\begin{array}{l}\text { - Terdapat pelebaran badan } \\
\text { sungai untuk menurunkan } \\
\text { kecepatan arus air. } \\
\text { - Terdapat cascade yang } \\
\text { berfungsi sebagai sedimen trap }\end{array}$ & $\begin{array}{l}\text { - Terdapat cascade yang } \\
\text { berfungsi sebagai sedimen } \\
\text { trap. }\end{array}$ \\
\hline $\begin{array}{l}\text { Vegetasi } \\
\text { penyerap polusi } \\
\text { air }\end{array}$ & $\begin{array}{l}\text { Terdapat segmen koridor } \\
\text { yang area sempadannya } \\
\text { ditanami pepohonan. }\end{array}$ & $\begin{array}{l}\text { Terdapat biokoridor } \\
\text { disepanjang sempadan sungai } \\
\text { pada salah satu sisi koridor. } \\
\text { Biokoridor terdiri dari berbagai } \\
\text { macam jenis pohon. }\end{array}$ & - Tidak tersedia \\
\hline $\begin{array}{l}\text { Penyedia } \\
\text { habitat satwa }\end{array}$ & $\begin{array}{l}\text { - Terdapat area alami yang } \\
\text { dipertahankan dengan }\end{array}$ & $\begin{array}{l}\text { Biokoridor dapat menjadi } \\
\text { sarana dalam migrasi satwa. }\end{array}$ & $\begin{array}{l}\text { - Minimnya jumlah pohon } \\
\text { berdampak pada minimnya } \\
\text { satwa pada RTH ini. }\end{array}$ \\
\hline
\end{tabular}




\begin{tabular}{|c|c|c|c|}
\hline Kriteria & Teras Cikapundung & Jaletreng River Park & Taman Kaulinan \\
\hline \multicolumn{4}{|c|}{ Fungsi ekologis } \\
\hline & $\begin{array}{l}\text { mayoritas pohon hutan, } \\
\text { untuk habitat satwa. } \\
\text { - Tersedia kolam yang } \\
\text { dikhususkan untuk } \\
\text { konservasi satwa air Sungai } \\
\text { Cikapundung. }\end{array}$ & & \\
\hline Kriteria & Teras Cikapundung & Jaletreng River Park & Taman Kaulinan \\
\hline \multicolumn{4}{|c|}{ Fungsi sosial } \\
\hline Interaksi warga & Sarana interaksi warga sekitar. & Sarana interaksi warga sekitar. & Sarana interaksi warga sekitar. \\
\hline $\begin{array}{l}\text { Tempat } \\
\text { rekreasi }\end{array}$ & $\begin{array}{l}\text { Tersedia area rendam kaki, } \\
\text { flying fox, amphiteater, air } \\
\text { mancur dan gazebo. }\end{array}$ & $\begin{array}{l}\text { Tersedia area rekreasi berupa } \\
\text { hammock, area duduk, dan } \\
\text { amphitheater. }\end{array}$ & $\begin{array}{l}\text { Tersedia area santai pada } \\
\text { playground }\end{array}$ \\
\hline $\begin{array}{l}\text { Objek } \\
\text { pendidikan, } \\
\text { penelitian, dan } \\
\text { pelatihan }\end{array}$ & $\begin{array}{l}\text { Tersedia area edukasi terkait } \\
\text { Sungai Cikapundung. }\end{array}$ & Tidak tersedia & Tidak tersedia \\
\hline Area bermain & $\begin{array}{l}\text { Tersedia area playground. } \\
\text { Tersedia permainan air sungai. }\end{array}$ & $\begin{array}{l}\text { Tersedia area playground } \\
\text { Tersedia permainan air sungai } \\
\text { berupa perahu bebek }\end{array}$ & Tersedia area playground \\
\hline Area olahraga & Tidak tersedia & Tersedianya area jogging track & $\begin{array}{l}\text { Tersedia area olahraga: panjat } \\
\text { tebing, skate board, lapangan } \\
\text { basket dan fitness. }\end{array}$ \\
\hline $\begin{array}{l}\text { Tempat } \\
\text { bertemu grup } \\
\text { kecil dan grup } \\
\text { besar }\end{array}$ & Tempat berkumpul komunitas & Tempat berkumpul komunitas & Tempat berdiskusi grup kecil \\
\hline $\begin{array}{l}\text { Adanya desain } \\
\text { kebudayaan } \\
\text { setempat }\end{array}$ & $\begin{array}{l}\text { Tidak terdapat desain } \\
\text { kebudayaan setempat }\end{array}$ & $\begin{array}{l}\text { Desain kebudayaan setempat } \\
\text { terlihat dengan adanya rumah } \\
\text { betawi yang difungsikan sebagai } \\
\text { kios }\end{array}$ & $\begin{array}{l}\text { Tidak terdapat desain } \\
\text { kebudayaan setempat }\end{array}$ \\
\hline
\end{tabular}

\section{Kesimpulan}

Mempelajari karakter dari desain RTH sempadan sungai perkotaan dapat menjadi masukan bagi kota lain yang hendak membangun RTH serupa. Kesimpulan yang didapat terkait karakteristik desain RTH sempadan sungai perkotaan dilihat dari fungsi ekologis dan fungsi sosial yaitu untuk kedua fungsi sebaiknya dapat dipenuhi dengan seimbang. RTH Teras Cikapundung dan RTH Jaletreng River Park adalah contoh dari RTH yang mewadahi kedua fungsi dengan baik. Letaknya yang berada di area sempadan sungai yaitu area konservasi, biasanya RTH sempadan sungai cenderung dominan pada fungsi ekologisnya, oleh karena itu diharapkan sungai juga dijadikan potensi dalam pemenuhan fungsi sosial.

Kesimpulan kedua terkait pemenuhan fungsi ekologis, sempadan sungai dipertahankan area alaminya agar habitat satwa dapat terjaga. Namun dapat dipadukan dengan area buatan berupa penguat untuk mencegah erosi dan sedimentasi sungai.

Kesimpulan ketiga terkait pemenuhan fungsi sosial, badan sungai dapat dimanfaatkan sebagai daya tarik pengunjung yaitu dengan cara mendesain area duduk menghadap sungai, mendesain area sirkulasi disepanjang sempadan sungai, serta mengadakan permainan sungai.

Saran bagi penelitian selanjutnya adalah mengukur keberagaman flora fauna pada RTH sempadan sungai untuk mengetahui keberhasilan desain RTH dalam pemenuhan fungsi ekologis. Selain itu dapat pula dilakukan penelitian mengenai kepuasan pengunjung pada desain RTH sempadan sungai dalam pemenuhan fungsi sosial.

\section{Ucapan terima kasih}

Ucapan terima kasih kepada Lembaga Penelitian dan Komersialisasi Teknologi (LPKT) Institut Teknologi Indonesia yang telah mendanai 
penelitian ini. Nomor kontrak 095/KP/LPKTITI/VI/2019.

\section{Referensi}

Adjam, Roosna Maryani Octaviana, and Emi Renoat. 2017. 'Vegetasi Lanskap Jalan Sebagai Pereduksi Aliran Angin Di Kota Kupang'. Jurnal Lanskap Indonesia, 63-72. https://doi.org/10.29244/jli.2017.9.1.63-72.

Angelia, Tisa. 2017. 'Konsep Pengembangan Ruang Terbuka Hijau Sebagai Fungsi Ekologis Penyerap Air Hujan Di Kecamatan Rungkut Kota Surabaya'. Institut Teknologi Sepuluh Nopember Surabaya.

Bowler, Diana E., Lisette Buyung-Ali, Teri M. Knight, and Andrew S. Pullin. 2010. 'Urban Greening to Cool Towns and Cities: A Systematic Review of the Empirical Evidence'. Landscape and Urban Planning 97 (3): $147-55$ https://doi.org/10.1016/j.landurbplan.2010.05 .006 .

Budiman, Ariev, Bambang Sulistyantara, and Alinda FM. Zain. 2014. 'Deteksi Perubahan Ruang Terbuka Hijau Pada 5 Kota Besar Di Pulau Jawa (Studi Kasus: DKI Jakarta, Kota Bandung, Kota Semarang, Kota Jogjakarta, Dan Kota Surabaya)'. Jurnal Lanskap Indonesia 6 (1): 7-15. https://doi.org/https://doi.org/10.29244/jli.20 14.6.1.7-15.

Direktoran Jenderal Penataan Ruang Departemen Pekerjaan Umum. 2008. Pedoman Penyediaan Dan Pemanfaatan Ruang Terbuka Hijau (RTH) Di Kawasan Perkotaan Permen PU No. 5/PRT/M/2008. Indonesia. http://pustaka.pu.go.id/biblio/pedomanpenyediaan-dan-pemanfaatan-ruang-terbukahijau-rth-di-kawasan-perkotaan-permen-puno-5prtm2008/EJ7D7.

Dwiyanto, Agung. 2009. 'Kuantitas Dan Kualitas Ruang Terbuka Hijau Di Permukiman Perkotaan'. TEKNIK 30 (2): 88-92. https://doi.org/https://doi.org/10.14710/teknik .v30i2.1861.

Erdianto, Alun, Siti Nurul Rofiqo Irwan, and Dody Kastono. 2019. 'Fungsi Ekologis Vegetasi Taman Denggung Sleman Sebagai Pengendali Iklim Mikro Dan Peredam
Kebisingan'. Vegetalika 8 (3): 139. https://doi.org/10.22146/veg.41374.

Fatah, Kemas Abdul, Arief Laila Nugraha, and Haniah. 2015. 'Kajian Perubahan Ruang Terbuka Hijau (RTH) Terhadap Pertumbuhan Industri Berbasis Geospasial (Studi Kasus: Kabupaten Gresik)'. Jurnal Geodesi Undip 4 (3): $1-10$. https://ejournal3.undip.ac.id/index.php/geode si/article/view/8953.

Givoni, B. 1991. 'Impact of Planted Areas on Urban Environmental Quality: A Review'. Atmospheric Environment. Part B. Urban Atmosphere 25 (3): 289-99. https://doi.org/10.1016/0957-1272(91)90001$\mathrm{U}$.

Hartoyo, Hansen, and Santoni. 2018. 'Kriteria Ruang Publik Kalijodo Pendukung Aksesibilitas Dan Peningkatan Aktivitas'. ARTEKS: Jurnal Teknik Arsitektur 2 (2): $113-24$

https://doi.org/10.30822/arteks.v2i1.45.

Imansari, Nadia, and Parfi Khadiyanta. 2015. 'Penyediaan Hutan Kota Dan Taman Kota Sebagai Ruang Terbuka Hijau (RTH) Publik Menurut Preferensi Masyarakat Di Kawasan Pusat Kota Tangerang'. Ruang 1 (3): 101-10. https://doi.org/https://doi.org/10.14710/ruang .1.3.101-110.

Kantartzis, A., G. Varras, P. Koutsikou, A. Papadopoulou, and C Gogolou. 2006. 'Greenway Planning and Management of Urban Riparian Corridors: The Alternative Basis for an Integrated System of Urban Green Spaces. Case Study: Riparian Corridors in the City of Igoumenitsa, Greece'. In Proceedings of the 5th WSEAS International Conference on Environment, Ecosystems and Development, 168-73. Venice, Italy: WSEAS International Conference on Environment, Ecosystems and Development.

Liem, Yoseph, and Reginaldo Chistophori Lake. 2018. 'Pemaknaan Ruang Terbuka Publik Taman Nostalgia Kota Kupang'. ARTEKS: Jurnal Teknik Arsitektur 2 (2): 149-58. https://doi.org/10.30822/arteks.v2i1.48.

Lukmanniah, Purwanti, and Indung Sitti Fatimah. 2016. 'Manfaat Kanopi Pohon Dalam Upaya Penyimpanan Dan Daya Serap Karbon Di Kawasan Perumahan'. Jurnal Lanskap Indonesia $\quad 8 \quad$ (1): 13-20. https://doi.org/10.29244/jli.2016.8.1.13-20.

Madjowa, Nona Fitriana. 2017. 'Fungsi Ekologi Sebagai Penyerap Limpasan Air Hujan Pada 
Taman Kota'. Fraktal: Jurnal Arsitektur, Kota Dan Sains 2 (2): 41-50. https://ejournal.unsrat.ac.id/index.php/fraktal/ article/view/20158/19763.

Naharuddin, Naharuddin. 2018. 'Komposisi Dan Struktur Vegetasi Dalam Potensinya Sebagai Parameter Hidrologi Dan Erosi'. Jurnal Hutan $\begin{array}{llll}\text { Tropis } & 5 & \text { (2): } & 134 .\end{array}$ https://doi.org/10.20527/jht.v5i2.4367.

Nurika, Famella Beatris Putri, Erry Wiryani, and Jumari. 2019. 'KeanekaragamanVegetasi Riparian Sungai Panjang Bagian Hilir Di KecamatanAmbarawa Kabupaten Semarang'. Jurnal Akademika Biologi 8 (1): 30-34. https://ejournal3.undip.ac.id/index.php/biolog i/article/view/24742/22144.

Persada, Citra, Novi Putri, and Dwi Bayu Prasetya. 2018. 'Kajian Fungsi Sosial Budaya, Estetika, Dan Ekologi Taman Hutan Kota Way Halim Kota Bandar Lampung'. In Seminar Nasional Hasil Penelitian Sains, Teknik Dan Aplikasi Industri, 246-50. Lampung: Fakultas Teknik, Universitas Lampung.
http://repository.lppm.unila.ac.id/13270/1/CR -2-69-makalah citra-sinta.pdf.

Presiden Republik Indonesia. 2007. UndangUndang Republik Indonesia Nomor 26 Tahun 2007 Tentang Penataan Ruang. Indonesia. https://jdih.kemenkeu.go.id/fullText/2007/26 TAHUN2007UU.HTM.

Ramdhani, Arief Yusuf, and Indung Sitti Fatimah. 2013. 'Studi Potensi Kanopi Pohon Di Kebun Raya Bogor Dalam Menyerap Emisi Karbondioksida Dari Kendaraan Bermotor'. Jurnal Lanskap Indonesia 5 (1): 41-46. https://doi.org/https://doi.org/10.29244/jli.20 13.5.1.\%25p.

Widyahantari, Rani, and Iwan Rudiarto. 2018. 'Kapasitas Pemerintah Kota Bandung Dalam Penyediaan Taman Tematik Guna Mewujudkan Kota Layak Huni'. Jurnal Pengembangan Kota $6 \quad$ (1): 9. https://doi.org/10.14710/jpk.6.1.9-16. 